\title{
The Reinforcement of Child's Independent Character Value through Humanistic-Based Family Education
}

\author{
Suyahman \\ Veteran Bangun Nusantara University of Sukoharjo \\ sym_62@yahoo.com
}

\begin{abstract}
This research aimed to describe the reinforcement of child's independent character value through humanistic-based family education in Wirogunan Village, Kartasura Sub District, Sukoharjo Regency. This study was a qualitative research with descriptive approach. Methods of collecting data were observation, interview and documentation. Data validation was carried out using data and method triangulations. Technique of collecting data used was an interactive model of analysis encompassing 3 stages: data reduction, data display, and data verification. The result of research showed that considering the result of field observation conducted by author on December 2, 2017 to February 10, 2018, it could be found that the independence of children in Wirogunan village is very poor, as most of them were still dependent on their parents and brothers/sisters, particularly in doing the assignment the teacher gives. This fact is supported with the habituation of family education that always spoiled the children and gave them inadequate trust and responsibility. One of solutions to this problem was to change education paradigm in family into the one that always supports the creation of child's independent character. Family education that could support child's independent character was humanistic-based family education. The conclusion was that humanistic-based family education could be a means of reinforcing child's independent character value.
\end{abstract}

Keywords: Independent character and Humanistic-based Family

\section{INTRODUCTION}

Thereare 18 nation character education values, one of which is independence. Independence is an attitude and behavior of not dependent easily on others in doing assignment. Other argument says that independent character is an attitude or behavior of acting not dependently on others in solvingproblems or doing assignment (Supinah and Parmi, 2011). Furthermore, according to Knowless (in Rusman, 2011), an independent student should have his/her own creativity and initiative as well as be able to work independently referring to guidance it obtains. Deli (year?) explains that independent character is a condition of an individual who can stand alone, grow and develop due to discipline and commitment thereby determining him/herself as expressed assessable action and behavior.

Independent character has important meaning to everyone. With all independent character, children will do all assignments responsibly. However, what occurs in Wirogunan Village of Kartasura Sub District of Sukoharjo Regency is the infringement against child's independent character. Considering the result of observation conducted by the author on February 2 to April 20, 2018 on 50 children in 8 RTs (neighborhood), it can be found that some attitudes, behaviors, and deeds do not reflect independent character: praying (sholat) when reminded by parent only, putting shoes and other school equipment haphazardly and their parents making them neat, parent arranging their bed neatly, washing and ironing their clothes, doing homework with parent's help, etc. The problem of research is stated as follows: how to reinforce the child's independent character through humanistic communication-based family education.

\section{THEORETICAL STUDY}

Child's independence is one factor requiring special attention to achieve adulthood optimally. Child's independence is oriented to doing job their parents entrust without others' help.Creating child's independent character is parent's duty. Therefore, parents are required to habituate independent character to their child everyday. Through this habituation, children will do their assignment consciously and without dependency on others.

An individual with independent character will use his/her knowledge he/she has gotten at school to create job opportunity and to make money. Meanwhile, an individual with employee or labor mentality will use the knowledge they have gotten at school to seek job and waste money, be always dependent on others. A success is the requirement to achieve independence. There is no success without hard work, independence, and there is no independence without independent character creation.

The importance of independent character requires us to keep learning and to begin doing small things in life. Here are some examples of building independent character in life: Trying to do everything alone without 
others' help or instruction, for example picking up rubbish.

Erikson (in Desmita, 2009: 185) states that the characteristics of individuals with independent character are: 1) capable of finding their own identity or fate, 2) having initiative and creativity, 3) making their own consideration in acting, 4) being responsible for their action, 3) capable of controlling themselves, and 6) capable of making their own decision. Nurhayati (2011: 148) asserts that there are some principles in growing child's independent character: 1) learn focus changes from teaching to learning, 2) attempt of affecting the students, 3) use peer support and cooperation, 4) exemplify self- assessment or friend assessment, 5) emphasize fully on individual's difference.

The attempt of growing child's independent character is the responsibility of family, school, and community. Family is obliged to grow independent character at home. Parents can habituate the child to have attitude, behavior, and deed reflecting independence. Parents should be the role model of attitude, behavior, and deed reflecting independence. For example, husband should not always have his wife catered to him in everything before their children, for example in making beverage, serving food, making the bed neat, doing office work, and etc.

Growing child's character through family education should be done using humanistic communication. Humanistic communication is defined as an interaction between child and parent based on attitude of appreciating and respecting each other. For that reason, obtrusiveness should be avoided, not to beselfish and attitude of not respecting others' opinion should be eliminated. Humanistic communication in family can grow the feelings of comfort, security, and peace to child. Humanistic communication is manifested into the harmonization between child and parent. Rudiyanto (2015) says that the main element of humanistic communication in family is harmonization of family relation.

\section{METHOD}

This study was a qualitative research. Bogdan and Taylor (year?) define "qualitative methodology" as a research procedureproducing descriptive data, including written or spoken words from individuals and observable behavior. Meanwhile, Kirk and Miller define qualitative research as certain tradition in social science fundamentally dependent on observation on human beings in their own area and related to those individuals in its discussion and terminology.

The methods of collecting data were observation, interview, and documentation. Data validation was carried out using an interactive model of analysis consisting of three stages: data reduction, data display, and data verification.

\section{RESULT AND DISCUSSION}

Independence is an individual's attitude and behavior reflecting individual (independent) deed, without others' help. Independence is identical with maturity (adulthood), doing something without being determined or directed fully by others. Through independence, a child will be able to determine the choice he/she considers as true; in addition, he/she decides on his/her choice bravely and is responsible for risk and consequence of the choice.

From the result of field observation conducted by the author, it can be found that some attitudes and behaviors do not reflect child's independence in Wirogunan Village, Kartasura Sub District, Sukoharjo Regency. They are: their clothes are still washed and ironed by parents and with laundry service;bag, shoes, and clothes are put tidily by their parents; food and beverage are prepared by their parents and parents still deliver and pick them up from school, children work on their homework with parents' help, children leave their house dirty without cleaning it, and they are not willing to make their bed nor clean their bathroom.

From the result of interview with20 parents conducted for 1 weeks from March 25 - April 2, 2018, the following information can be obtained: child should be woken up, should be reminded to do sholat, does not want to wash dishes after meal, does not want to make their own bed neat, does not want to fold their own clothes, does not want to make their own room and cupboard neat, does not want to make their own studying tableneat, and should be told compulsively to study. Meanwhile, from the result of interview with 15 children conducted from April 3 to 10, 2018, the following information can be obtained: child does not want to do their domestic works because of household assistant's presence, does not want to do their homework because of difficulty and inability and their parents call private teacher, does not want to make their bed neat, does not want to wash dishes after meal, does not want to wash and iron their clothes because of the household assistance's presence, singleness, and laziness. Child should be told to do Sholat, and should be woken up because their parents do not give role model, they simply order the child's around.

From the result of field observation, interview with parents, and interview with child, it can be seen that the independent character of children in Wirogunan Village, Kartasura Sub District, Sukoharjo Regency is seen very worrisome. For that reason, solution to it should be found. One of it is to reinforce the independent character through family education with humanistic communication.

\section{Discussion}

The fair level of fear can function as protective emotion to children, enabling them to find out when they should ask adults or their parent for protection. Such independence is defined by Northrup as a child's ability of making choice he/she considers as right, of making decision bravely, and being responsible for the risk and consequence of their choice. 
Referring to the definition, there are at least eight elements accompanying the meaning of independence to a child: ability of making choice; ability of making choice bravely; ability of being responsible for and receiving the consequence of his/her choice; selfconfidence; self-direction; self-development; selfadjustment with environment; and bravery in taking risk of their choice. Developing the child's independence in principle is to give him/her opportunity of participating in many activities. The more the opportunities given to child, the more skilled and the more self-confident is the child.

Considering the result of research, the attempts taken to reinforce child's independent character through humanistic communication-based family education are as follows. 1) Children are encouraged to do daily activities themselves such as taking a bath, brushing tooth, having meal, combing hair, dressing, and so on as soon as they have been capable of doing so. 2) Children are given opportunity of making theirown decision if necessary, for example, choosing cloth to be worn. 3) Children will be given opportunity of playing without parents accompany, thereby they are skilled in developing their idea and thinking. To prevent accident, the playing room is arranged in such a way that no hazardous object is put there. 4) Let children do everything themselves despite some mistake. 5) When parents play with children, please play according to the child's wish, if the child is dependent on parent, motivate him/her to take initiative and support his/her decision. 6) Encouragethe child to reveal his/her idea. 7) Encourage the children to socialize themselves,so that they will learn to deal with a more complex socialproblem. When children are in doubt or fear, try to accompany them first, so that they do not feel being compelled. 8) Invite the older children to deal with domestic chores, such as watering plant, cleaning table, sweeping the room, and feeding cats 9) When children try to understand time concept, encourage them to organize their personal schedule, for example, when they will study, play, and rest. Parents can accompany them by asking their reason of time management. 10) Children should also be given responsibility and consequence when they do not comply with their responsibility. It helps children develop the feeling of meaningfulness and discipline. 11) Health and power usually relate to independence as well, thereby it is necessary to give healthy menu to children and invite children to do some physical exercisesor physical activities. 12) Give children the opportunity of making choice. Children accustomed with situation or something specified by others will do their own choice lazily. Otherwise, when they are accustomed with dealing with some choices, they will be skilled in making their own decision. 13) Appreciate their effort. Appreciate even the little effort taken by children to deal with their difficulty themselves. Parents are usually patient in dealing with children who take a long time to open a can of candy themselves, particularly when her mother is burry in the kitchen. 14) Avoid posing some questions. The questions posed by parents actually intended to show the children's attention can be defined as curiosity. Therefore, avoid having fussy image. 15) Never give answer directly. Although one of parent's duties is to give correct information and knowledge to children, parents may not answer the questions posed directly. Otherwise, give them an opportunity of answering the question. It is the parent'sjob to correct their incorrect answer or to appreciate the correct one. 16) Encourage them to see some other alternatives. Children should know that to deal with a problem, parent is not the only one to which a question is posed. Many sources are available out of home that can help them solve the problem encountered. For that reason, the way the parents can take is to inform them about the correct source they can ask for help. 17) Never break their spirit. Parents often want avoid children from disappointment by saying "it is impossible" over what the children are doing. When children have been willing to show their wish to be independent, keep motivating them to do so. Never make them losing their motivation or expectation.

\section{CONCLUSION}

Considering the result and discussion, it can be concluded that humanistic-based family education is highly significant to be implemented in reinforcing the child's independent character in Wirogunan, Kartasura Sub District, Sukoharjo Regency.

\section{REFERENCES}

[1]. Alberta Education.The Heart of Matter: Character and Citizenship Education in Alberta School. 2005.

[2]. Berkowitz, Marvin W. dan Bier, Mellinda C. What Works in Character Education: A Research-driven Guide for Educators. Washington: Character Education Partnership. 2005.

[3]. Cholisin. "Konsolidasi Demokrasi Melalui Pengembangan Karakter Kewarganegaraan, "Jurnal Civics, Vol. 1, No. 1, Juni, pp. 14-28. 2004.

[4]. Crome, Keith, Ruth Farrar and Patrick O'Connor. What is Autonomous Learning? Journal Volume: 9, Number: 1, Start Page 111126. 2009.

[5]. Hidayatullah, M Furqon. Pendidikan Karakter Membangun Peradaban Bangsa. Surakarta: Yuma Pustaka. 2010.

[6]. Kesuma, Dharma, dkk. Pendidikan Karakter Kajian Teori dan Praktik di Sekolah. Bandung: PT Remaja Rosdakarya. 2011.

[7]. Kirschenbaum, Howard. "From Values Clarification to Character Education: A Personal Journey." The Journal of Humanistic Counseling, Education and Development. Vol. 39, No. 1, September, pp. 4-20. 2000.

[8]. Moleong, Lexy J.Metodologi Penelitian Kualitatif. Bandung: Remaja Rosdakarya. 1995. 
[9]. Mikarsa.Pendidikan dalam keluarga Jakarta, Karya Ilmu. 2004

[10]. Masrun. Studi Tentang Kemandirian Sebagai Kualitas Kemandirian, Makalah Seminar IlmuIlmu Sosial: Mempersiapkan Masyarakat Masa Depan di Ujung Pandang. 1988.

[11]. Narwanti. Pendidikan Karakter Pengintegrasian 18 Nilai Dalam Mata Pelajaran, Yogyakata: Familia.2011.

[12]. Sugiyono. Memahami Penelitian Kualitatif. Bandung: Alfabeta. 2005.

[13]. Sumahamijaya, Suparman et. all. Pendidikan Karakter Mandiri dan Kewiraswastaan. Bandung: Angkasa.2003.
[14]. Tuloli, J.H. Transformasi Potensi Generasi Muda Menuju Insan Mandiri: Menguak Kegiatan Pembina Pramuka di Indonesia, Disertasi. 1991

[15]. Williams, Mary M. "Models of Character Education: Perspectives and Developmental Issues." The Journal of Humanistic Counseling, Education and Development. Vol. 39, No. 1, September, pp. 32-40. 